\title{
Pemberdayaan Perangkat Desa Terampil Bermedia dalam Membangun Kesadaran dan Kepedulian Masyarakat terhadap Lingkungan di Desa Cikeruh Kecamatan Jatinangor Kabupaten Sumedang
}

\section{The Empowerment of Skilled-Media Village Officials in Building Public Awareness and Concern for the Environment in Cikeruh Village, Jatinangor District, Sumedang Regency}

\author{
Feliza Zubair*, Iriana Bakti, Yustikasari
}

Prodi Hubungan Masyarakat, Fakultas Ilmu Komunikasi, Universitas Padjadjaran, Jl. Raya Bandung - Sumedang, KM 21, Jatinangor, 45363, Indonesia

\begin{tabular}{l}
\hline Info Artikel \\
\hline Diterima 13 Oktober 2019 \\
Ditelaah 13 Nopember 2019 \\
Disetujui 30 Desember 2019 \\
Tersedia daring 31 Desember \\
2019 \\
*Penulis untuk korespondensi \\
feliza.zubair@unpad.ac.id \\
\hline \\
Kata Kunci: \\
Perangkat Desa, \\
Media sosial, \\
Facebook, \\
Instagram
\end{tabular}

Keywords:

Village apparatus,

Social media,

Facebook,

Instagram

\section{ABSTRAK}

Perangkat desa merupakan ujung tombak pemerintahan desa yang bertugas menyampaikan dan mengolah berbagai informasi berkaitan dengan program-program pemerintah baik pusat maupun daerah. Di zaman yang serba digital ini, hampir semua arus informasi dilakukan melalui media sosial. Untuk itu, diperlukan perangkat desa yang terampil dan cakap terutama dalam menggunakan serta memanfaatkan perangkat media sosial. Pemerintah desa dapat mensosialisasikan program estafet pemerintah maupun informasi lainnya kepada warga sekitar melalui media sosial. Pelayanan perangkat Desa Cikeruh melalui media sosial belum maksimal. Oleh karena itu, pelatihan mengelola media sosial terutama dalam sosialisasi masalah kebersihan lingkungan perlu diadakan. Universitas Padjadjaran merupakan salah satu perguruan tinggi yang memegang amanah untuk melakukan pengabdian kepada masyarakat melalui kegiatan pendidikan dan penelitian. Pengabdian pada masyarakat yang terintegrasi dengan kuliah kerja nyata mahasiswa ini dilaksanakan di Desa Cikeruh, Kecamatan Jatinangor, Kabupaten Sumedang. Metode pelatihan yang digunakan adalah metode ceramah dan diskusi serta praktek langsung. Peserta mendapatkan berbagai pengetahuan berkaitan dengan pengelolaan pesan dan penggunaan media sosial khususnya facebook dan instagram. Hasil kegiatan menunjukan peningkatan pengetahuan, sikap dan perilaku peserta dalam hal penggunaan media instagram serta facebook dalam pembenahan dan penataan lingkungan di Cikeruh.

\section{ABSTRACT}

The village government staff is the spearhead of the village government duty whose job
is to deliver and process various information relating to government programs, both
central and regional government. In this digital era, almost all information flow is carried
out through social media. For this reason, a skilled and capable village government staff
is needed, especially in using and utilizing social media devices. Through social media,
the village government able to socialize the government's relay program and other
information to residents. The village service of Cikeruh village through media social has
not run optimally. Therefore, training in managing social media, especially in the
socialization of environmental hygiene issues, must be held. Universitas Padjadjaran is
one of the higher education institutions holding the mandate of community service
through education and research activities. This community service integrated with
student work college was held in Cikeruh village, Jatinangor District, Sumedang
Regency. The training method was lecture and discussion methods, as well as hands-on
practice. Participants gained various knowledge related to message management and the
use of social media, especially Facebook and Instagram. The results of the activity were
the increasing of the knowing, attitudes, and behavior of participants in using Instagram


and Facebook to increase effort in improving and restructuring the environment in Cikeruh Village.

ISSN 2685-0354 (Media Online). Diterbitkan oleh Universitas Prof. Dr. Hazairin, SH. Ini merupakan jurnal bebas akses di bawah lisensi Creative Commons Atribution 4.0 International (https://creativecommons.org/licenses/by/4.0)

\section{PENDAHULUAN}

Tugas dan kewajiban perangkat desa tertulis di dalam Peraturan Menteri Dalam Negeri Nomor 83 Tahun 2015 tentang Pengangkatan dan Pemberhentian Perangkat Desa, yang kemudian direvisi dalam Peraturan Menteri Dalam Negeri Nomor 67 Tahun 2017, yaitu perangkat desa bertugas membantu Kepala Desa dalam penyusunan kebijakan dan koordinasi pada sekretariat desa. Di era aplikasi program Nawa Cita ke-3 Presiden Joko Widodo, perangkat desa memiliki peranan yang semakin penting untuk memperkuat pembangunan desa karena percepatan pembangunan desa Indonesia dimulai dari desa-desa dan daerah daerah pinggiran.

Percepatan pembangunan di pedesaan membutuhkan perangkat desa yang terampil dan cakap terutama dalam menggunakan serta memanfaatkan perangkat media komunikasi guna memperkenalkan situasi dan kondisi desa kepada masyarakat luas. Salah satu media yang tepat digunakan dan dipergunakan oleh hampir setiap orang saat ini adalah media sosial. Setiap desa dapat memperkenalkan berbagai potensi yang dimilikinya dengan proses yang sederhana dan sangat mudah melalui media sosial.

Desa Cikeruh berada dalam kawasan pendidikan Jatinangor yang terdapat 4 kampus besar di Indonesia yaitu Universitas Padjadjaran, Institut Teknologi Bandung, Institut Koperasi Indonesia dan Institut Pemerintahan Dalam Negeri. Sisi positif dari kehadiran universitas-universitas di kawasan ini adalah dapat menghidupkan perekonomian masyarakat sekitar, seperti usaha tempat makan, laundry, fotokopi, usaha kos-kosan, apartemen, penginapan termasuk pusat-pusat perbelanjaan yang cukup lengkap seperti Jatinangor Town Square atau Jatos.

Desa Cikeruh menghadapi beberapa permasalahan, seperti masalah keamanan dan masalah bergesernya budaya yaitu hilangnya kearifan lokal yang dianut oleh masyarakat asli Desa Cikeruh. Masalah lain yang paling membebani pemerintahan desa adalah kebersihan lingkungan terutama pengelolaan sampah yang belum maksimal. Masih banyak warga yang membuang sampah di sembarang tempat seperti Sungai Cikeruh yang mengakibatkan sungai menyempit dan dangkal. Pengelolaan air bersih dan limbah rumah tangga juga menjadi masalah yang sulit dipecahkan, termasuk hilangnya daerah resapan air akibat pembangunan kontrakan dan apartemen. Kawasan Jatinangor sangat rentan terhadap banjir, terutama jika hujan deras turun agak lama.

Tim pengabdi melakukan pemetaan kebutuhan masyarakat dan peta permasalahan di Desa Cikeruh yang dilihat dari berbagai aspek sosial dan budaya, faktor ekonomi, pendidikan, kesehatan, lingkungan, agama serta letak geografis. Hasil wawancara dengan Sekretaris Desa Cikeruh, Rudi, menggambarkan bahwa penggunaan media sosial telah dilakukan tetapi masih terbatas di lingkungan pengurus desa. Sebelumnya, untuk memperoleh dukungan masyarakat, pihak desa melakukan sosialisasi kepada masyarakat melalui rukun tetangga (RT), rukun warga (RW), Pemberdayaan Kesejahteraan Leluarga (PKK) dan Perlindungan Masyarakat (Linmas) secara door to door maupun dalam beberapa pertemuan rutin. Hasilnya belum maksimal. Karena itu, diperlukan upaya lain yang dapat lebih mudah diterima masyarakat yaitu melalui media sosial. Surat edaran disampaikan melalui pesan WhatsApp. Media ini digunakan untuk penyampaian pesan antara pemerintah desa dengan perangkat desa hingga pengurus RT dan RW.

Pada kenyataannya perkembangan teknologi dan informasi mengarahkan pengguna pada pemanfaatan internet. Daya pikat internet menurut Holmes (sebagaimana dikutip dalam Budiman, 2017) disebabkan karena internet membebaskan informasi dan penggunanya untuk bergerak tanpa batasan. Miranda dan Lubis (2017) menjelaskan bahwa Indonesia merupakan salah satu negara dengan pengguna instagram terbanyak. Instagram saat ini merupakan media sosial kedua yang banyak dikunjungi setelah facebook. Arianti (2017) menjelaskan jumlah pengguna aktif instagram di Indonesia berdasarkan data monnthly active user mencapai 22 juta pengguna.

Desa Cikeruh sudah memiliki media instagram dan facebook saat ini. Namun, penggunaannya tidak maksimal karena tidak ada pengelola khusus. Kepala Desa Cikeruh (Ii Sujai), dan Sekretaris Desa berencana untuk menggunakan kedua media tersebut dalam memperkenalkan potensi-potensi yang dimiliki desa dan menyampaikan program-program pemerintah kepada masyarakat dalam membangun kesadaran dan kepedulian masyarakat terhadap lingkungan. Aparat Desa Cikeruh memerlukan pelatihan agar lebih terampil menggunakan dan mengelola pesan melalui media instagram dan facebook. Menurut Cahyono (2016), mengakses media sosial sudah merupakan kebutuhan. Untuk itu, upaya untuk memutakhirkan informasi diperlukan setiap saat agar terjaga keaktualitasannya. Dengan pelatihan ini, aparat desa Cikeruh diharapkan dapat mengelola media sosialnya dan mengupdate informasi terbaru secara teratur. 
Kelebihan instagram menurut Poetra dan Christantyawati (2016) adalah memungkinkan pengguna berbagi foto menerapkan filter digital dam menyebarkan pada berbagai layanan jejaring sosial. Media instagram dianggap sebagai media sosial yang paling menarik karena lebih fokus pada penayangan foto-foto dan video berdurasi pendek (15 detik s.d. 1 menit) yang dapat diakses oleh publik (Nasrullah, 2015). Oleh karena itu, instagram dapat berdampak bagi pencitraan seseorang ataupun suatu lembaga dalam hal ini adalah pemerintahan desa. Maanfaatnya antara lain adalah masyarakat dapat berinteraksi langsung dengan aparat desa kapanpun, tidak terbatas ruang dan waktu.

Hasil penelitian Juwita, Budimansyah dan Nurbayani (2015) menyimpulkan bahwa pengguna internet merasa bosan dan ketinggalan informasi bila tidak mengakses media sosial karena media sosial memudahkan mereka memperoleh informasi dan memperluas pertemanan. Masyarakat Desa Cikeruh dapat memperoleh berbagai informasi secara cepat dan akurat berkaitan program-program terbaru desa, peraturan-peraturan, dan informasi-informasi penting lainnya.

Facebook juga dikenal sebagai situs jejaring sosial yang banyak digunakan karena sangat aplikatif. Sherlyanita dan Rakhmawati (2016) menjelaskan bahwa media sosial dengan penetrasi tertinggi di Indonesia ditempati oleh facebook. Namun dalam kenyataan penggunaannya menurut hasil penelitian Simangunsong (2016), tidak terjadi arah hubungan non-intimate menjadi intimate. Facebook seharusnya digunakan untuk memperkuat hubungan atau mencari hubungan dengan orang lain. Faktanya, komunikasi yang disampaikan dengan kata-kata yang tidak etis justru menyinggung pengguna lain.

Pengabdian pada masyarakat (PPM) yang dilakukan oleh dosen dapat didesminasikan melalui Kuliah Kerja Nyata Mahasiswa (KKNM). PPM-KKNM merupakan suatu bentuk pengabdian kepada masyarakat untuk mengaplikasikan ilmu yang sudah diterima selama perkuliahan. Tim PPM-KKNM 2019 memilih mengadakan pelatihan keterampilan dalam bermedia sosial khusunya instagram dan facebook untuk membantu memberikan solusi atas permasalahan kesadaran dan kepedulian masyarakat Desa Cikeruh. Tujuan PPM adalah untuk memenuhi kebutuhan masyarakat khususnya perangkat Desa Cikeruh agar lebih terampil dalam menggelola media sosial sesuai dengan etika dan peraturan. Setiap peserta pelatihan akan membawa pengetahuan dan pengalaman yang diperoleh dalam pelatihan dan ini akan berpengaruh pada perkembangan pengetahuan dan kemampuannya.

\section{METODE}

PPM ini dilaksanakan pada 26 Juni 2019 sampai dengan 26 Juli 2019 (Tabel 1 dan Tabel 2) di Desa Cikeruh, Kecamatan Jatinangor, Kabupaten Sumedang yang merupakan bagian dari stakeholder Universitas Padjadjaran. Kegiatan PPM dilaksanakan di Ruang Serbaguna Desa Cikeruh. Sasaran kegiatan PPM adalah perangkat desa Cikeruh dan masyarakat umum yang diwakili oleh ibu-ibu PKK, Pos Pelayanan Terpadu (Posyandu), Kelompok Wanita Tani (KWT), Karang Taruna, ketua RW dan ketua RT di lingkungan Desa Cikeruh.

Tabel 1. Tahapan kegiatan KKNM-PPM integratif

\begin{tabular}{|c|c|c|c|c|}
\hline \multirow{2}{*}{ No } & \multirow{2}{*}{ Rencana Kegiatan } & \multicolumn{3}{|c|}{ Keterlibatan dalam kegiatan } \\
\hline & & Dosen & Mahasiswa & Wakil Masyarakat \\
\hline 1 & Persiapan & $\begin{array}{l}\text { Melakukan pemetaan } \\
\text { khalayak Desa Cikeruh } \\
\text { dan permasalahannya }\end{array}$ & $\begin{array}{l}\text { Melaksanakan koordinasi } \\
\text { dengan aparat desa dan } \\
\text { masyarakat dalam persiapan } \\
\text { PPM }\end{array}$ & $\begin{array}{l}\text { Adanya pendataan } \\
\text { kesediaan dari pihak } \\
\text { aparat desa dan } \\
\text { jajarannya untuk ikut } \\
\text { PPM }\end{array}$ \\
\hline 2 & Pelaksanaan & $\begin{array}{l}\text { Melaksanakan penetapan } \\
\text { dan pengelolaan kegiatan } \\
\text { PPM }\end{array}$ & $\begin{array}{l}\text { Ikut terlibat dalam } \\
\text { pelaksanaan PPM }\end{array}$ & $\begin{array}{l}\text { Berpartisipasi dalam } \\
\text { kegiatan PPM }\end{array}$ \\
\hline 3 & Monitoring & $\begin{array}{l}\text { Kesesuaian dan } \\
\text { ketepatan penggunaan } \\
\text { metode dan penggunaan } \\
\text { media sesuai PPM }\end{array}$ & $\begin{array}{l}\text { Ikut terlibat melakukan } \\
\text { monitoring kepada semua } \\
\text { peserta }\end{array}$ & $\begin{array}{l}\text { Memberikan respon } \\
\text { terhadap pelaksanaan } \\
\text { PPM }\end{array}$ \\
\hline 4 & Evaluasi & $\begin{array}{l}\text { Melakukan evaluasi } \\
\text { peningkatan pengetahuan } \\
\text { dan kemampuan }\end{array}$ & $\begin{array}{l}\text { Membantu melakukan } \\
\text { evaluasi kepada para peserta } \\
\text { PPM }\end{array}$ & $\begin{array}{l}\text { Memberikan respon dan } \\
\text { penilaian terhadap } \\
\text { pelaksanaan PPM }\end{array}$ \\
\hline
\end{tabular}


Tabel 2. Agenda acara pelatihan

\begin{tabular}{|c|c|c|c|c|}
\hline No & Waktu & Agenda & Pengisi & Keterangan \\
\hline 1 & $13.00-14.00$ & Registrasi Peserta & Mahasiswa KKNM 2019 & Isi daftar hadir \\
\hline 2 & $14.00-14.15$ & Pembukaan dan sambutan & $\begin{array}{l}\text { Ketua KKNM } 2019 \\
\text { Ketua DPL } \\
\text { Sekdes }\end{array}$ & $\begin{array}{l}\text { MC mahasiswa KKNM } \\
2019\end{array}$ \\
\hline 3 & $14.15-14.20$ & Pretest & Peserta & \\
\hline 4 & $14.20-15.20$ & $\begin{array}{l}\text { Materi 1: Manajemen pesan } \\
\text { melalui media instagram }\end{array}$ & $\begin{array}{l}\text { Dr. Iriana Bakti dan tim } \\
\text { KKNM } 2019\end{array}$ & $\begin{array}{l}\text { Teknik pembuatan } \\
\text { instagram dan mengemas } \\
\text { pesan persuasif }\end{array}$ \\
\hline 5 & $15.20-16.20$ & $\begin{array}{l}\text { Materi 2: Manajemen pesan } \\
\text { melalui media facebook }\end{array}$ & $\begin{array}{l}\text { Dr. Feliza Zubair dan Tim } \\
\text { KKNM } 2019\end{array}$ & $\begin{array}{l}\text { Tehnik pembuatan } \\
\text { facebook dan mengemas } \\
\text { pesan persuasif }\end{array}$ \\
\hline 6 & $16.20-17.20$ & Tanya jawab dan post test & $\begin{array}{l}\text { Dr. Yustikasari dan tim } \\
\text { KKNM } 2019\end{array}$ & \\
\hline 7 & $17.20-18.00$ & Penutup dan foto bersama & Panitia dan peserta & \\
\hline
\end{tabular}

Metode yang digunakan adalah ceramah, diskusi dan praktek. Instruktur menyampaikan materi secara lisan melalui metode ceramah dengan tujuan untuk membentuk pengetahuan dan pemahaman peserta mengenai tata cara menggunakan media sosial dan bagaimana mengelola media sosial khususnya facebook dan instagram, apa fungsinya, apa tujuan pengadaan media sosial dan lainnya. Instruktur juga menyampaikan materi tentang etika bermedia sosial, tata krama dan hukum-hukum dalam menggunakan media sosial.

Metode berikutnya adalah pelatihan praktis atau praktek. Metode praktek dalam kegiatan ini merupakan suatu upaya untuk membimbing peserta secara sistematis dan terarah untuk lebih maksimal menggunakan media sosial, mengelola pesan dan menyampaikan pesan lingkungan. Peserta menjadi lebih terampil, efisien dan bijak dalam menggunakan media sosial. Peserta mendapatkan pengalaman langsung dalam membuat instagram dan facebook dengan bantuan pelaksana kegiatan yaitu mahasiswa dan dosen.

Tim melakukkan pre-test pada awal pelatihan dan post-test di akhir pelatihan untuk menilai pengetahuan peserta terhadap penggunaan dan pemanfaatan media sosial, khususnya media instagram dan facebook yang selama ini pernah dilakukan dan setelah diberi pelatihan. Hal ini dapat digunakan sebagai salah satu indikator keberhasilan dalam pelaksanaan kegiatan pengabdian kepada masyarakat dari sisi kognitif para peserta pelatihan (Tabel 2). Ada 10 pertanyaan yang ditanyakan dengan sistem pilihan ganda, yaitu berkaitan dengan pengetahuan peserta tentang media sosial, kegunaannya, dampak-dampaknya serta pengetahuan tentang bagaimana membuat dan mengelola akun instagram dan akun facebook.

Tim bekerjasama dengan aparat Desa Cikeruh, RT, RW, PKK dan KWT melakukan kegiatan monitoring dan evaluasi secara berkala dan berkesinambungan untuk mendapatkan informasi perkembangan perilaku masyarakat pada tahap-tahap selanjutnya. Monitoring dan evaluasi juga melibatkan para mahasiswa KKNM periode April 2019 sampai dengan Nopember 2019.

Tabel 3. Indikator keberhasilan kegiatan

\begin{tabular}{|c|c|c|c|}
\hline No & Indikator & Base line (sebelum kegiatan) & Pencapaian setelah kegiatan \\
\hline 1 & Kognitif & $\begin{array}{l}\text { Peserta masih kurang paham tentang } \\
\text { pengetahuan pengelolaan pesan pada } \\
\text { media instagram dan facebook }\end{array}$ & $\begin{array}{l}\text { Peserta mengetahui tentang pengelolaan pesan } \\
\text { pada media instagram dan facebook }\end{array}$ \\
\hline 2 & Afeksi & $\begin{array}{l}\text { Kurang peka terhadap pesan yang } \\
\text { membangun kesadaran masyarakat } \\
\text { terhadap lingkungan }\end{array}$ & $\begin{array}{l}\text { Peka terhadap pengelolaan pesan yang dapat } \\
\text { membangun kesadaran masyarakat terhadap } \\
\text { lingkungan }\end{array}$ \\
\hline 3 & Konatif & $\begin{array}{l}\text { Perilaku yang interaktif dalam } \\
\text { menggelola pesan pada instagram dan } \\
\text { facebook }\end{array}$ & $\begin{array}{l}\text { Perilaku yang responsif dalam mengelola pesan } \\
\text { yang dapat membangun kesadaran masyarakat }\end{array}$ \\
\hline
\end{tabular}




\section{HASIL DAN PEMBAHASAN}

Kegiatan ini merupakan integrasi pengadian pada masyarakat (PPM) dan kuliah kerja nyata mahasiswa (KKNM) sehingga pelaksananya adalah dosen pelaksana PPM dan mahasiswa peserta KKNM (Gambar 1). Keterlibatan mahasiswa adalah sebagai pembawa acara, pelaksana administratif, moderator dan pembimbing praktek membuat akun instagram maupun facebook yang didampingi oleh tim dosen. Kegiatan diawali dengan penjajakan ke pihak pimpinan desa dan pembuatan surat izin sebagai syarat admistratif kegiatan. Koordinasi dengan Sekretaris Desa Cikeruh dilakukan untuk mensosialisasikan kegiatan kepada seluruh jajaran atau aparat Desa Cikeruh melalui surat undangan dari pihak Desa.

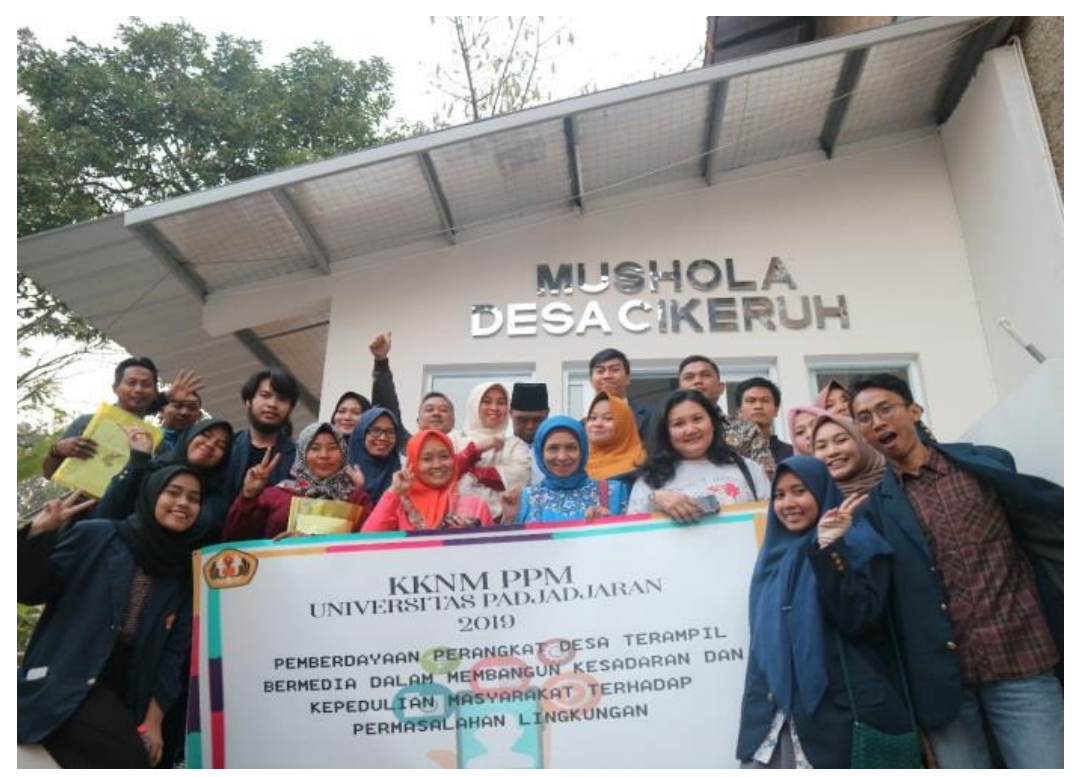

Gambar 1. Peserta dan panitia KKNM PPM Desa Cikeruh sebelum melakukan pelatihan

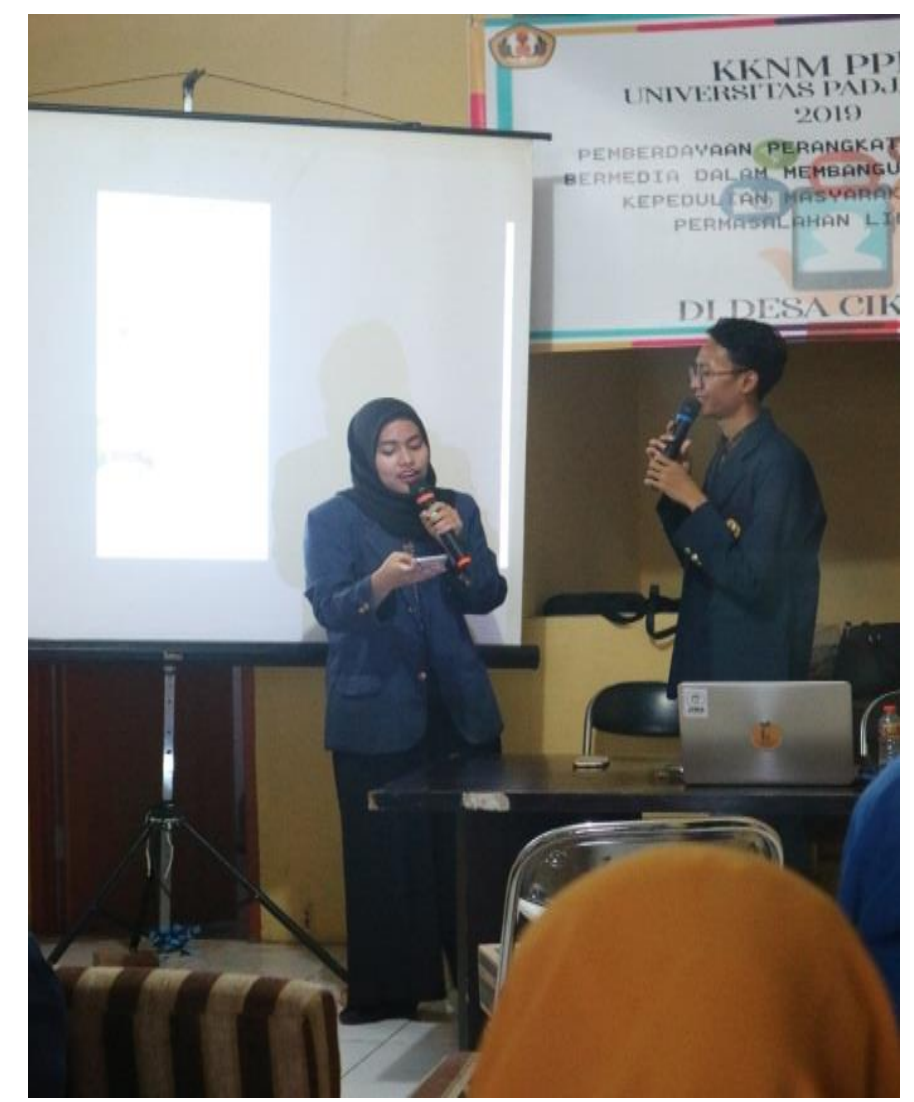

Gambar 2. Pemberian materi dan simulasi oleh tim instruktur 
Pelatihan dilaksanakan pada tanggal 26 Juli 2019 di ruang serbaguna Desa Cikeruh (Gambar 2 dan Tabel 2). Materi pertama mencakup manajemen instagram dan etika bermedia sosial. Pentingnya pengelolaan dan pengemasan pesan yang tepat, khususnya melalui media sosial, untuk mencapai tujuan komunikasi lingkungan yang efektif guna mengajak masyarakat Desa Cikeruh agar mau berpartisipasi mewujudkan program-program kebersihan dan pelestarian lingkungan disampaikan melalui materi pertama. Media sosial dinilai memiliki banyak kelebihan sehingga lebih praktis dan efektif. Masyarakat diajarkan bagaimana membangun dan mengelola pesan yang persuasif dan sederhana namun bila disampaikan secara terus-menerus dan berulang-ulang akan dapat menimbulkan kesadaran warga untuk peduli pada lingkungan. Scramm, sebagaimana dikutip dalam Mulyana (2001), menyatakan bahwa pesan-pesan harus disusun sedemikian rupa agar berhasil membangkitkan perhatian dan keinginan khalayak yaitu harus direncanakan, menggunakan simbol-simbol bahasa yang dipahami kahalayak, membangkitkan kebutuhan pribadi khalayak dan memberikan jalan bagi pemenuhan kebutuhan khalayak tersebut. Hal ini yang disebut sebagai komunikasi lingkungan oleh Agustin (2016) yaitu suatu pesan yang dikemas sedemikian rupa dengan berbagai media untuk menyadarkan khalayak akan pentingnya memperhatikan lingkungan.

Materi kedua adalah pelatihan mengelola akun facebook. Facebook masih merupakan media sosial terpopuler di Indonesia (Pertiwi, 2019). Berdasarkan penelitian Jakpat, sebagaimana dikutip dalam Priliantini dan Damayanti (2018), facebook dinobatkan sebagai Indonesia Social Media Trend Q3 2016 dengan perolehan pengguna sebanyak 84,6\% dari seluruh pengguna media sosial. Hasil pra-survei mahasiswa Tim KKNM menunjukkan data bahwa hampir semua peserta pelatihan memiliki akun facebook dan menggunakannya untuk kepentingan-kepentingan pribadi.

Peserta juga dibekali pengetahuan tentang etika dan tata krama saat menggunakan media sosial, khususnya media instagram dan facebook. Materi disampaikan oleh tim dosen secara aplikatif dan tidak teoritis. Hal ini berkaitan dengan usia peserta yang mayoritas sudah berumur di atas 40 tahun. Beberapa etika bermedia sosial yang disampaikan adalah berkaitan dengan pemilihan kata-kata yang tepat dan tidak menyinggung orang lain tetapi dapat mecapai tujuan yang diharapkan. Pemilihan foto-foto juga harus cermat dan sopan. Undang-undang Nomor 19 Tahun 2016 tentang Informasi dan Transaksi Elektronik yang berkaitan dengan pelanggaran susila, perjudian, pencemaran nama baik, penyebaran berita bohong atau hoax dan lain-lain juga disampaikan dalam pelatihan ini.

Pelatihan praktis difokuskan pada tata cara membuat akun instagram dan facebook secara praktek langsung yang dipandu oleh tim mahasiswa KKNM 2019. Instruktur menyampaikan langkah-langkah membuat akun instagram kepada para peserta. Beberapa fasilitator berada di antara peserta untuk membantu dan membimbing para peserta yang kesulitan mengikuti instruksi pelatihan. Yang banyak menarik minat peserta adalah mengunggah foto dan pesan atau informasinya. Fasilitator memberikan penjelasan bahwa foto-foto yang akan diunggah di instagram sebaiknya memiliki makna informasi mengingat tugas dari para peserta sebagai perangkat desa yang harus menyampaikan informasi yang jelas kepada masyarakat. Peserta diperkenalkan dengan beberapa istilah dalam bermedia sosial seperti follow, like, comment, dan mention. Bagian ini menekankan bahwa penggunaan instagram dan facebook harus dapat memfasilitasi distribusi informasi secara merata dengan memanfaatkan fitur-fitur yang bagus untuk dapat membuat foto-foto lebih indah dan artistik. Beberapa contoh yang disampaikan berkaitan dengan informasi lingkungan adalah masalah sampah dan kegiatan Jumat Bersih.

Contoh penyampaian pesan dalam pengelolaan sampah yang baik dan menjaga lingkungan yang bersih di Desa Cikeruh adalah dengan menyajikan potensi-potensi yang dimiliki desa dan menampilkan profil desa sebagai lokasi favorit. Kemudian, pengelola media sosial desa mengajak warga dan follower untuk peduli membenahi titik-titik rawan sampah dan banjir. Informasi tata cara pemilahan sampah dan hasil pengolahan sampah oleh ibu-ibu PKK desa Cikeruh juga harus disampaikan untuk mendorong warga dalam mengolah sampah.

Banyak hal yang dapat diperkerkenalkan dan dipromosikan melalui media sosial berkaitan dengan potensi Desa Cikeruh. Setiap RW di Desa Cikeruh memiliki berbagai macam potensi baik budaya, ekonomi, kesehatan dan pendidikan. Dalam bidang budaya dan kesenian beberapa RW masih memiliki kesenian Reak, calung, kuda lumping, dan kecapi dimana pelestariannya dilakukan oleh Karang Taruna. Potensi lain yang dimiliki lain oleh Desa Cikeruh, salah satunya, adalah produksi senapan angin. Namun, potensi-potensi tersebut tidak dapat diperkenalkan secara maksimal oleh pihak desa karena pihak desa masih memiliki keterbatasan dalam mempromosikannya. Potensi-potensi tersebut diharapkan dapat dikenal secara luas dengan meningkatkan kualitas komunikasi melalui media sosial.

Tim PPM-KKNM juga menjelaskan beberapa dampak negatif media sosial antara lain sikap malas bergaul, kecanduan, penyebaran hoax. Menggunakan media sosial secara berlebihan dapat mengganggu kesehatan dan pekerjaan. Penyebaran berita hoax di media sosial sering mengganggu ketenangan warga seperti penculikan, penipuan, pemalsuan identitas, penjualan barang terlarang dan sebagainya. Hal ini perlu diantisipasi oleh pengelola media sosial Desa Cikeruh. 
Untuk menguji keberhasilan, indikator keberhasilan dalam pelatihan ini diukur berdasarkan tingkat pengetahuan (kognitif), tingkat pemahaman (afektif) dan tingkat perilaku interaktif (konatif) peserta. Pre test dan post-tes yang dilaksanakan pada saat pelatihan bertujuan untuk mengukur pencapaian pengetahuan peserta pelatihan sebelum dan sesudah mengikuti pelatihan (Gambar 3). Hasil pre-test menunjukan bahwa 50\% peserta PPM menjawab benar. Hasil post-test menunjukkan bahwa $70 \%$ peserta menjawab benar. Hal ini menunjukkan bahwa pelatihan PPM KKNM 2019 ini telah berhasil meningkatkan pengetahuan (kognisi) peserta tentang membuat media sosial dan meningkatkan pemahaman peserta tentang etika bermedia sosial.

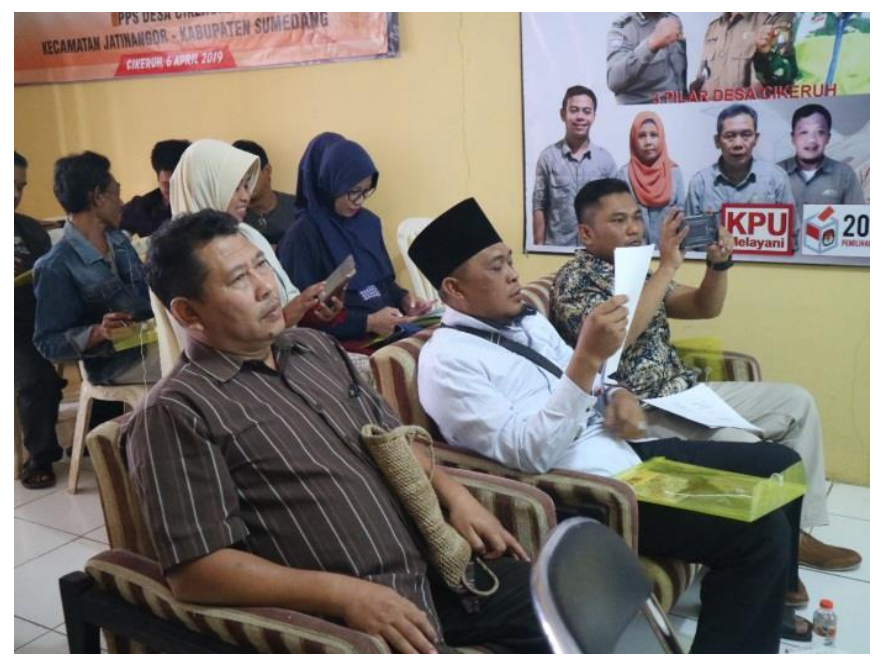

Gambar 3. Pengisian pre-test oleh peserta pelatihan

Kegiatan ini diharapkan akan memberikan manfaat langsung kepada aparat desa Cikeruh dan semua peserta pelatihan agar memiliki kemampuan dan keterampilan praktis dalam pengelolaan media sosial, khususnya facebook dan instagram yang dapat diaplikasikan dikemudian hari. Kemampuan dan keterampilan ini diharapkan dapat disebarluaskan kepada para pengurus organisasi Desa Cikeruh yang lain dan organisasi pemerintahan lainnya di seluruh Indonesia. Kredibilitas dan citra positif Desa Cikeruh dapat ditingkatkan dengan bekal pengetahuan dan keterampilan mengelola media sosial yang baik.

\section{KESIMPULAN}

Penggunaan media instagram dan facebook secara tepat dapat membentuk opini masyarakat. Untuk itu, pengetahuan dan keterampilan aparat desa sangat diperlukan sebagai ujung tombak pelaksanaan program lingkungan di Desa Cikeruh. Pelatihan mengelola pesan melalui media sosial dapat memberikan manfaat yang bisa diterapkan oleh aparat desa dalam menggunakan media sosial dan membentuk komunikasi yang lebih efisien untuk kegiatankegiatan lingkungan di Desa Cikeruh. Hasil pre-test dan post-test yang dilakukan memberi gambaran bahwa pelatihan cukup berhasil. Dengan bekal pengetahuan dan keterampilan mengelola media sosial yang baik, aparat desa dapat meningkatkan kredibilitas dan citra positif Desa Cikeruh.

\section{DAFTAR PUSTAKA}

Agustin, H. (23 Desember 2016). Komunikasi Lingkungan Berperan Menyadarkan Khalayak Menjaga Lingkungan [Blog]. Diambil dari http://www.unpad.ac.id/profil/dr-herlina-agustin-s-sos-m-t-komunikasi-lingkunganberperan-menyadarkan-khalayak-menjaga-lingkungan/

Arianti, G. (2017). Kepuasan remaja terhadap penggunaan media sosial instragram dan path. Wacana: Jurnal Ilmiah Ilmu Komunikasi, 16(2), 180-192.

Budiman, A. (2017). Berita bohong (hoax) di media sosial dan pembentukan opini publik. Info Singkat : Pusat Pengkajian Pengolahan Data dan Informasi, 9(1), 17-20.

Cahyono, A. S. (2016). Pengaruh media sosial terhadap perubahan sosial masyarakat di Indonesia. Publiciana: Jurnal Ilmu Sosial dan Ilmu Politik, 9(1), 140-157.

Juwita, E. P., Budimansyah, D., \& Nurbayani, S. (2015). Peran media sosial terhadap gaya hidup siswa SMA Negeri 5 Bandung. Jurnal Sosietas, 5(1), 17-24 
Miranda, S., \& Lubis, E. E. (2017). Pengaruh instagram sebagai media online shopping fashion terhadap perilaku konsumtif mahasiswi Fakultas Ilmu Sosial Dan Ilmu Politik Universitas Riau. Jurnal Online Mahasiswa Fakultas Ilmu Sosial Dan Ilmu Politik Universitas Riau (e-journal), 4(1), 1-15.

Mulyana, D. (2001). Ilmu Komunikasi: Suatu Pengantar. Bandung, Indonesia: Rosda.

Nasrullah, R. (2015). Media sosial (perspektif komunikasi, budaya, dan sosioteknologi). Jakarta, Indonesia: Simbiosa Rekatama Media.

Pertiwi, W. K. (05 Februari 2019). Facebook jadi medsos paling digemari di indonesia. Kompas.com. diambil dari https://tekno.kompas.com/read/2019/02/05/11080097/facebook-jadi-medsos-paling-digemari-diindonesia?page $=$ all

Poetra, R. R., \& Christantyawati, N. (2017). Model AIDA: Pola penggunaan media sosial dalam meningkatkan kepuasan penjualan di Toko Online Goldies Hijab. Jurnal Komunikasi Profesional, 1(1), 22-36.

Priliantini. A., \& Damayanti. D (2018). Peran media sosial "facebook" dalam membentuk solidaritas kelompok pada aksi 411 dan 212. Jurnal Komunikasi, Media dan Informatika, 7(1), 37-46.

Sherlyanita, A. K., \& Rakhmawati, N. A. (2016). Pengaruh dan pola aktivitas penggunaan internet serta media sosial pada siswa SMPN 52 Surabaya. Journal of Information Systems Engineering and Business Intelligence, 2(1), $17-22$.

Simangunsong, B. A. (2016). Interaksi antar manusia melalui media sosial facebook mengenai topik keagamaan. Jurnal Aspikom, 3(1), 65-76. 